\title{
Artelogie
}

Recherche sur les arts, le patrimoine et la littérature de l'Amérique latine

1 | 2011

Brésil, questions sur le modernisme

\section{Genealogia e identidade familiares no teatro de Ariano Suassuna}

\section{Eduardo Dimitrov}

\section{OpenEdition}

Journals

Edição electrónica

URL: https://journals.openedition.org/artelogie/8676

DOI: 10.4000/artelogie.8676

ISSN: 2115-6395

\section{Editora}

Association ESCAL

Refêrencia eletrónica

Eduardo Dimitrov, «Genealogia e identidade familiares no teatro de Ariano Suassuna», Artelogie [Online], 1 | 2011, posto online no dia 01 março 2011, consultado o 07 janeiro 2022. URL: http:// journals.openedition.org/artelogie/8676 ; DOl: https://doi.org/10.4000/artelogie.8676

Este documento foi criado de forma automática no dia 7 janeiro 2022

Association ESCAL 


\title{
Genealogia e identidade familiares no teatro de Ariano Suassuna
}

\author{
Eduardo Dimitrov
}

1 Ariano Suassuna, dramaturgo e romancista paraibano radicado em Recife, hoje desfruta do reconhecimento da crítica como um dos grandes escritores brasileiros vivos. Principalmente suas peças de teatro foram fundamentais para a constituição do moderno teatro brasileiro, como afirmaram Sábato Magaldi e Décio de Almeida Prado ${ }^{1}$.

2 Seus textos para teatro mais famosos foram escritos entre 1955 e 1959: Auto da Compadecida, em 1955; O Santo e a Porca e O Casamento Suspeitoso, ambas em 1957; A Pena e a Lei, em 1959. Ariano destacou-se na medida em que, em todas as suas peças, positivou o sertão e os sertanejos. A população da região mais árida do país não era apenas sofredora e faminta, mas valente, alegre e, principalmente, esperta.

3 Também na década de 1950, Ariano tinha outro projeto que não conseguiu levar adiante de maneira tão exitosa quanto suas peças: tratava-se de uma biografia de seu pai. Em função de uma grande "intriga", nos termos de Ana Claudia Marques², causada por disputas políticas, no interior da oligarquia Pessoa ${ }^{3}$, João Suassuna foi assassinado em 1930.Apesar de ter apenas três anos de idade quando o pai foi morto, Ariano, em muitos artigos, entrevistas e outros textos publicados, constrói narrativas sobre seu pai como se tivesse convivido mais tempo com ele. Por exemplo, ele lembra-se do modo como o pai montava ou tratava os animais.

4 Será, então, que toda essa "carga emocional" que o impediu de escrever a biografia de seu pai não estava ativada também na fatura das peças ? Será que é possível isolar o autor das peças do autor frustrado da biografia ? Em outras palavras, de que maneira a memória construída em um contexto específico informa a produção dramatúrgica de um autor considerado um dos responsáveis pela modernização do teatro brasileiro ?

5 Escrever a biografia do pai não era uma possibilidade muito inusitada para um integrante de uma extensa família nordestina. A escrita de livros de genealogia, biografias e de fatos e vultos é uma atividade comum nestes grupos familiares ${ }^{4}$. Aliás, João Suassuna foi biografado por outros parentes, que não o seu filho. Natércia Suassuna Dutra Ribeiro Coutinho, além de escrever a biografia de João Suassuna em 
2000, dedicou-se a escrever a história de seus antepassados no livro História de Duas Vidas: Adilia e Natércio. Raimundo Suassuna escreveu o livro Uma Estirpe Sertaneja: Genealogia da Familia Suassuna, publicado em 1993, no qual, contando a história da família, delimita a abrangência dos laços de parentesco. O irmão de Ariano, João Suassuna Filho, por sua vez, descreve as consequências da disputa de 1930 sobre a vida cotidiana da família em outro livro publicado em 2000.

6 Se Ariano, na década de 1950, não foi capaz de redigir a biografia de seu pai, na década de 1970 ele passa a escrever sobre a história de sua família no semanário recifense $O$ Jornal da Semana. No conjunto desses artigos, desenvolve uma narrativa nos mesmos moldes dos seus parentes, não em forma de livro, e sim de crônicas semanais. Uma espécie de genealogia em fascículos que, tomados em conjunto, tem uma narrativa semelhante daquela do livro de seu irmão, João Suassuna Filho. Ou seja, selecionam histórias e acontecimentos que dão identidade à sua grei e indicam fronteiras, oposições, inimigos e amigos em cada um dos acontecimentos.

7 Nesses artigos da década de 1970, é possível depreender a maneira como Ariano constrói uma história e uma identidade familiar. Essa construção elucidará as escolhas estéticas feitas pelo dramaturgo no momento da fatura de suas obras ficcionais.Não se trata de colocar uma narrativa sobre a outra, ou de explicar as peças a partir dos artigos em que Ariano discorre sobre a história de sua família. As peças, dessa forma, também podem ser lidas como uma outra forma encontrada pelo escritor para construir essa identidade familiar. Assim como nas genealogias, as peças exaltam alguns valores caros aos Suassuna e depreciam outros, característicos de seus opositores. Dialogando com livros de genealogias, fatos e vultos, biografias etc., as peças inserem-se num sistema outro, que não propriamente o dramatúrgico. Elas fazem parte de disputas simbólica, travadas pelas grandes famílias, pela construção de uma imagem para o Nordeste.

8 Neste artigo, busca-se mostrar essa outra inserção das peças de Ariano não apenas em um campo teatral, mas principalmente em um campo político desenhado a partir da Paraíba dos anos 1930, onde as famílias assumem centralidade. Para tanto, utilizou-se os artigos escritos por Suassuna na década de 1970 no Jornal da Semana no qual ele narra o seu ponto de vista dos acontecimentos que desembocaram nos assassinatos de João Pessoa por João Dantas, tio materno de Ariano; de João Suassuna e do próprio Dantas, como vingança da morte de João Pessoa.Foi pelo casamento de sua irmã mais velha com um integrante da parentela de Epitácio Pessoa que João Suassuna formou-se como político seguindo sua carreira até ser eleito Presidente da Paraíba, cargo equivalente ao do atual Governador, em 1924. Durante seu mandato as divergências no interior da oligarquia tornaram-se mais acirradas. Ariano Suassuna descreve esse momento da carreira política de seu pai com a ideia de que ele fora um injustiçado e constantemente acusado de privilegiar o sertão ${ }^{5}$.

9 João Suassuna, na ótica do filho, seria um político justo. Olhava para os sertanejos, historicamente esquecidos, sem que isso significasse o abandono da capital. Ariano reforça ainda a origem camponesa do pai e sua integridade, pois ele não se esqueceria de sua terra no momento em que poderia ajudá-la. o pai, dessa maneira, representa o campo e a "pureza", a despeito de sua posição central na política que, a princípio, o afastaria de sua origem.

10 Nesse mesmo artigo, Ariano explicita a dicotomia que se desenhou no interior da oligarquia Pessoa nos anos pré-revolução de 1930. Segundo o dramaturgo, as famílias unidas em torno de Epitácio Pessoa - os Pessoa, os Suassuna, os Cunha Lima, os Dantas, 
entre outras - estariam assumindo novas posições e cindindo a oligarquia com base em diferenças de origens socioeconômicas: rural e urbana ${ }^{6}$.

11 Para Ariano, as posições tomadas por João Suassuna em defesa do sertão desagradou o setor urbano da oligarquia Pessoa e os atritos gerados entre as duas metades se agravaram ao longo da gestão de Suassuna.O momento da ascensão de João Suassuna no interior da oligarquia coincide com um período em que havia uma ausência de parentes mais próximos ao senador Epitácio Pessoa para assumir cargos de destaque (Deputado Estadual, Federal e Presidente de Província). Esse relativo vazio permitiu João Suassuna passar por algumas dessas funções até assumir o Governo do Estado. No entanto, quando chegou a este cargo, uma nova geração emergente de integrantes da família Pessoa atingia a idade e a formação necessária para assumir tais posições. Isso colabora para aumentar os atritos entre Suassuna - e seus aliados mais distantes do centro da parentela - e o setor que buscava manter os cargos de mando com parentes mais próximos. O lançamento da candidatura de João Pessoa para a sucessão de João Suassuna foi um dos episódios de retomada do centro por parte da oligarquia.

Segundo o dramaturgo, a candidatura de João Pessoa não foi bem recebida pelos parceiros de João Suassuna. No entanto, pelo que conta Ariano, seu pai era o mais prudente entre eles, e, como líder político influente, acalmou os ânimos de seus colegas convencendo-os a apoiar João Pessoa nas eleições. Os Dantas, por exemplo, sempre foram inimigos da família Pessoa, mas como Rita de Cássia Dantas Villar casara-se com João Suassuna, e este era aliado dos Pessoa, principalmente dos de Umbuzeiro, os Dantas se aproximaram dos Pessoa e os apoiaram nas eleições.

13 Aqui é interessante notar a variação da ênfase nas alianças de acordo com a posição do observador. Ariano afirma que os Dantas se aproximaram dos Pessoa pelo casamento de João Suassuna. Já a historiadora Linda Lewin afirma que Suassuna, criado muito próximo ao coronel Antônio Pessoa, se afastava pouco a pouco da oligarquia na medida em que suas convicções políticas o ligavam ao desenvolvimento do sertão. Esse afastamento teria sido expresso e agravado no fato dele ter se ligado "a um poderoso grupo de base familiar dos sertões [os Dantas], grupo esse considerado [...] como altamente suspeito entre os auxiliares mais próximos de Epitácio"?

14 Com esse contraponto, fica mais nítido o processo de construção da memória familiar em que Ariano está envolvido: suas seleções tornam-se mais claras. De qualquer modo, é o próprio Ariano quem narra, do seu ponto de vista, os detalhes desse emaranhado de alianças políticas e familiares que tomaram conta do cenário de $1930^{8}$. Segundo Ariano, uma vez eleito, João Pessoa iniciou seu Governo perseguindo os suassunistas e os coronéis sertanejos 9 . O nosso dramaturgo faz de João Pessoa, assim, um traidor inconsequente. Pinta-o como se, de repente, passasse a negar os "antigos aliados fiéis".

15 João Pessoa adota uma série de medidas que desagradam os coronéis sertanejos colaborando para acirrar, cada vez mais, a polarização sertão versus cidade. Três desses elementos, talvez os principais, foram: a guerra tributária, a tentativa de desarmamento dos jagunços dos coronéis e a perseguição, por parte de João Pessoa, a funcionários ligados aos sertanejos.

16 O algodão produzido no interior do Estado era, em grande parte, escoado por Recife. Principalmente a produção das regiões mais a oeste, que não contavam com uma boa infraestrutura de estradas. Além disso, o porto de Recife possibilitava o acesso de navios maiores, com grande calado, o que as águas rasas de Cabedelo não permitiam.Muitas empresas comerciais de Recife atuavam nesse trânsito por terra de 
mercadorias entre os Estados. Os Pessoa de Queiroz, por exemplo, tinham tráfego livre nas estradas da Província, até o momento em que João Pessoa passou a cobrar altos impostos pelas mercadorias saídas das fazendas rumo à fronteira. Obrigou, assim, os produtores da Paraíba a utilizarem o porto de Cabedelo.

17 João Pessoa tentava estabelecer uma maior independência com relação à Capital pernambucana garantindo a arrecadação do Estado. Ao mesmo tempo, porém, desagradou os produtores rurais, pois obrigou-os a gastarem mais com o transporte até a capital - devido às péssimas estradas, a viagem até Cabedelo era mais custosa do que até Recife - ou com altos impostos ao cruzarem a fronteira por terra.

João Pessoa, em outra medida, criou um imposto sobre as armas de fogo, na tentativa de desarmar os exércitos privados. Essa política, conforme Ariano Suassuna, foi entendida como contraditória, pois essas armas que agora eram taxadas pelo Estado da Paraíba, haviam sido entregues aos coronéis na gestão de João Suassuna para combater o cangaceirismo. Ariano dá pouca importância, em seus artigos, a esse fato, no entanto José Pereira Lima, principal aliado de João Suassuna, viu-se extremamente acuado, uma vez que ele detinha o maior poder bélico do oeste paraibano.

19 Além dos impostos, que incidiam sobre a produção agrícola e também sobre a posse de armas de fogo, João Pessoa removeu alguns funcionários. Em Princesa, por exemplo, foi retirado de seu cargo o chefe da Mesa de Renda, irmão de José Pereira. Indicou, também, a saída do prefeito de Princesa, além do prefeito e chefe político de Brejo da Cruz, o irmão de João Suassuna, Antônio Suassuna ${ }^{10}$.

20 Ariano não se detém nessas ligações de seu pai com o cangaceirismo sugeridas por Lewin. Diz apenas que João Suassuna perseguiu cangaceiros. Aqui há uma oscilação. Conta, com certo orgulho, o fato do pai ter três cavalos com nome de integrantes do bando de Lampião, mas sempre se defende das possíveis relações familiares entre cangaceiros e os Suassuna, que não parecem ser poucas ${ }^{11}$.

21 Além dos problemas políticos que cindiram a oligarquia, havia também uma divisão causada por diferenças de produção e consumo de bens culturais. Em diversos momentos, Ariano orgulha-se de seu pai, por ele ter sido um defensor e amante da cultura popular. Diz que, enquanto era governador da Paraíba, João Suassuna "escandalizou uma porção de gente porque costumava levar para o Palácio cantadores, músicos populares etc." ${ }^{12}$.Linda Lewin também atribui a crescente diferenciação dos costumes entre as elites urbanas e agrárias como um fator de cisão da oligarquia ${ }^{13}$. A diferenciação dos interesses geoeconômicos foi acompanhada de uma diferenciação de discurso legitimador para cada extrato da elite paraibana. De um lado, os citadinos valorizando seus novos hábitos modernos e, de outro, os sertanejos, como Suassuna, promovendo festivais de violeiros. A cultura surge, portanto, como um elemento para marcar diferenças e identidades, para salientar as disputas simbólicas e políticas que se desenrolavam em torno desses dois diferentes grupos sociais.

o pai de Ariano era, também, um colecionador de folhetos de cordel. João Suassuna colaborou, assim como João Dantas, na coletânea organizada por Leonardo Motta, Violeiros do Norte, publicada pela Cia. Graphico-Editora Monteiro Lobato em 1925. Ariano conta que seu pai adorava passar a noite com o "povo" das fazendas ouvindo histórias e desafios. Como se vê, Ariano costura elementos culturais "do povo" à figura de seu pai e à sua própria identidade. 


\section{As peças} artigos no Jornal da Semana. Ele selecionou e valorizou, colocando no centro da cena, elementos que caracterizam a sua família. $O$ ambiente, os personagens e o tipo de relação estabelecida entre os personagens mantêm referências à forma com que o autor enxerga a inserção de sua parentela nas disputas políticas descritas acima. Desse modo, não se trata de identificar rebatimentos ou reflexos da história narrada dissertativamente nos artigos agora transfiguradas em peças de teatro. Trata-se de identificar a forma como Ariano Suassuna se insere em um universo específico de relações e como ele responde a este universo quando escreve artigos genealógicos ou peças ficcionais de teatro. Suassuna foi criado por uma configuração social específica, mas também é criador de novas formas de representar e tornar inteligível esse universo. As peças, assim como os textos genealógicos, colaboram para a construção de uma identidade familiar em meio a uma disputa simbólica sobre o que é o Nordeste, o sertão, a cidade.

Todos os textos dramáticos de Ariano Suassuna têm o sertão inóspito, pois o sol e a seca são sempre agressivos, como pano de fundo. A fome é uma ameaça constante, principalmente para os personagens mais pobres. Esse ambiente pode estar mais ou menos em cena. Uma Mulher Vestida de Sol passa-se no pátio de casas vizinhas. Tanto em Auto da Compadecida como em A Pena e a Lei e em A Farsa da Boa Preguiça, a cena ocorre em praças públicas. Já $O$ Desertor de Princesa, O Casamento Suspeitoso e O Santo e a Porca têm como ambiente o interior de residências localizadas em pequenas cidades do sertão.

o Desertor de Princesa, Auto da Compadecida, O Casamento Suspeitoso e A Pena e a Lei ocorrem em Taperoá, cidade cede dos Dantas, família materna de Ariano. As outras peças não especificam a localização exata, mas se passam, de acordo com as indicações, sempre em pequenas cidades. Os personagens conhecem-se e há referências a outros não atuantes, mas que são conhecidos de todos, dando a impressão de que cada um tem noção da totalidade da população do local.

Em O Casamento Suspeitoso, por exemplo, a cidade era tão pequena que havia apenas um automóvel, o de Herotides, personagem conhecido por todos sem, no entanto, aparecer em cena. $O$ hotel de Dadá é referência tanto em $O$ Casamento Suspeitoso como em $O$ Santo e a Porca, apesar de a última não indicar a cidade onde se passa. Suassuna trabalha com personagens estereotipados: o esperto, o coronel, o padre, o valente etc. Utiliza-se muito dos personagens de folhetos de cordel e de teatros de mamulengo, como João Grilo, Mateus, Benedito. São todos personagens existentes em histórias populares desenhados por Ariano à sua maneira.

Escrita em 1955, Auto da Compadecida é baseado em três folhetos de cordel: $O$ Enterro do Cachorro, História do Cavalo que Defecava Dinheiro e $O$ Castigo da Soberba. A ligação com a cultura popular é enfatizada pelo próprio Ariano não só na indicação dos folhetos de origem como nas rubricas que direcionam o tipo de montagem exigido. Ele começa a primeira marcação da seguinte maneira: "O Auto da Compadecida foi escrito com base em romances e histórias populares do Nordeste. Sua encenação deve [...] portanto, seguir a maior linha de simplicidade, dentro do espírito em que foi concebido e realizado"14. A trama gira em torno de dois personagens pobres que lutam para sobreviver: João Grilo e Chicó. Esses 
dois amigos tentam se vingar dos patrões exploradores e do Padre, mais interessado em bens materiais do que na vida espiritual.

Grilo busca sempre levar vantagens das situações. Por meio de suas artimanhas, consegue contornar as dificuldades. Ele está no leque de personagens espertos que, com suas variações, também se encontram em outras peças de Suassuna, como por exemplo Caroba e Pinhão, em $O$ Santo e a Porca, e Cancão, em $O$ Casamento Suspeitoso ${ }^{15}$.A peça tem início com Grilo e Chicó tentando convencer o Padre a benzer o cachorro moribundo da Mulher do Padeiro, sua patroa. Ao perceber que o Padre se recusaria, Grilo rapidamente elabora uma estratégia e afirma que o cachorro era do Major Antônio Morais, o grande coronel da região. $O$ sacerdote, então, aceita benzer o animal.

Em função de contratempos com o Major, o Padre decide não mais benzer bicho nenhum e o cachorro morre. Em face ao desespero da patroa, para contornar a situação, Grilo consegue - inventando a história em que o cachorro havia deixado em testamento uma quantia para o Padre e outra para o Sacristão - fazer o enterro em latim, já que o Padre não quis benzê-lo em vida.

As confusões geradas por Grilo dão comicidade à peça. Como quando vende à sua patroa um gato que "descome dinheiro", pois sabe que a fraqueza da Mulher do Padeiro era "bicho e dinheiro"; enrola o Bispo, que estava furioso com o mau comportamento do Padre perante o Major Antônio Morais, acrescentando-o no testamento do finado cachorro, entre outras.João Grilo arma um plano com a bexiga que tirou do cachorro antes dele ser enterrado. Esse plano consistia em encher a bexiga de sangue e escondêla debaixo da roupa no peito de Chicó. Em um dado momento, Grilo simularia matar Chicó e, em seguida, tocando uma rabeca, faria o suposto defunto ressuscitar. 0 leitor não consegue descobrir para quem se destinava essa armação, pois a entrada do cangaceiro Severino de Aracaju, matando praticamente todos os personagens, atrapalha o andamento da vingança de Grilo.

31 Na presença do Cangaceiro, Grilo muda rapidamente o alvo de seu plano como única forma de escapar. Supostamente, mata Chicó que ressuscita ao escutar o som da rabeca. Chicó adiciona ao plano uma estratégia de convencimento para que o Cangaceiro se deixe matar. Diz que quando "morto" viu Padre Cícero chamando por ele. Emocionado pelo chamamento do beato, o vilão deixar-se matar pelo seu Cabra, que depois tocaria a rabeca trazendo-o de volta à vida. Severino morre. Vendo que foi enganado, o Cabra mata João Grilo.

Essa vingança usando a bexiga era, provavelmente, destinada ao Padeiro e sua Mulher ${ }^{16}$, mas a invasão de Severino obrigou o personagem esperto a, rapidamente, adequar seus planos e utilizar o artifício em uma estratégia de defesa.Enfim, com a matança promovida por Severino de Aracaju de quase todos - com exceção de Chicó e do Frade o terceiro e último ato só poderia ser encenado no céu, num grande julgamento das almas pelo Demônio, por Jesus e pela Compadecida.

No julgamento, o cangaceiro e seu comparsa são redimidos de imediato. Cristo reconhece que suas vidas foram sofridas e que todos seus atos são justificados por terem sido meros instrumentos da cólera do Demônio. Os outros (Sacristão, Padre, Bispo, Padeiro e a Mulher), por intervenção de João Grilo, que apelou para Nossa Senhora, foram para o purgatório. Já Grilo, com a promessa de que iria se comportar melhor, conseguiu permissão para ressuscitar.João Grilo é pobre e esperto. Suassuna caracteriza a "esperteza como a coragem do pobre"17. Dada uma situação avessa, o esperto é capaz de pensar rapidamente em um plano para contorná-la e conseguir 
atingir o seu objetivo. No caso de Grilo, não só contornou as situações em vida como, durante o julgamento divino, conseguiu a salvação para todos os personagens, mesmo que passando pelo purgatório, e a sua ressurreição, proeza comparável a de Jesus Cristo.

Em A Pena e a Lei, por sua vez, há uma generalização acerca desse tipo de personagem esperto. No primeiro ato, baseado em Torturas de um Coração, Benedito tem um objetivo claro em mente: casar-se com Marieta. Faz tudo para atingi-lo. Enfrenta os dois pretendentes da moça: Vicentão e o Cabo Rangel ${ }^{18}$, os homens mais valentes de Taperoá. Enquanto se preocupava com o mais difícil - desafiar os valentes -, foi traído pelo próprio amigo Pedro, que conquista Marieta.

No segundo ato, Benedito é chamado para servir de advogado do vaqueiro Mateus, acusado de roubar um novilho do fazendeiro Vicente. Benedito faz a defesa de modo exemplar, mas a prova decisiva foi arranjada pelo próprio Mateus: uma declaração da prefeitura dizendo que o animal foi para o matadouro a mando de Vicente. A declaração, porém, era do ano anterior e Mateus é quem teve a ideia de utilizá-la, apostando que ninguém repararia na data. Foi ele quem forjou a prova, mostrando-se assim mais esperto que Benedito, que também fora enganado.

O verdadeiro ladrão do novilho - o realmente esperto - não era nem Benedito, nem Mateus; mas Joaquim, que presenciou o processo e trapaceou todos. O que mais chama a atenção em A Pena e a Lei é o fato de não haver apenas um personagem esperto: há uma generalização. 0 "povo miúdo", o vaqueiro, o pobre são todos espertos, mas para causas individuais e particulares. Os personagens espertos agem por conta própria para atingir objetivos que lhes dizem respeito ou a amigos muito próximos. Os pobres, que se confundem com espertos, não se pensam como classe e, portanto, não agem para o bem de todos. Muito pelo contrário, estão sozinhos, no máximo pedem algum tipo de ajuda, como Mateus, que solicitou auxílio a Benedito para provar sua inocência. As ações são, dessa maneira, pontuais e visam a um benefício particular.Outras passagens poderiam ser destacadas como exemplo do personagem esperto, mas essas, extraídas dos textos mais famosos, já permitem vislumbrar a forma como Suassuna constrói o ambiente e os personagens de suas peças.

\section{Genealogia e teatro}

37 A recorrente ambientação das peças de Suassuna, em meios rurais ou pequenas cidades do interior, acaba por alinhar o dramaturgo a mesma origem sertaneja de sua família. Ariano não é um autor nascido no interior que, migrado para um grande centro urbano, como Recife onde reside desde a juventude, passa a escrever ficção em cenários urbanos. Ao contrário, optou por localizar suas peças, e mesmo seus romances e poesias, em um ambiente predominantemente rural e muitas vezes nominalmente situado em Taperoá, cidade de origem da família materna e local onde passou boa parte de sua infância.A essa opção de identificar o ambiente das peças com o local de origem de sua família pode ser adicionada a descrição que faz do povo sertanejo. A construção da imagem do sertanejo esperto em Auto da Compadecida e em A Pena e a Lei não difere muito daquela construída nos artigos do Jornal da Semana ${ }^{19}$. Pode-se traçar alguns paralelos entre as peças apresentadas e o trecho do artigo reproduzido na nota xx. Em ambos há uma filiação de Ariano ao povo sertanejo. Se nos textos teatrais o leitor é induzido a simpatizar com João Grilo, Chicó e Benedito, o polo 
pobre e esperto da história, no artigo Ariano também valoriza a esperteza dos sertanejos que, mesmo sem possuir tanto poder bélico como a polícia da Paraíba, enfrenta-a com uma coragem exemplar.

Suassuna atribui a Luís do Triângulo, insinuando certo sertanejo típico, a ideia de armar a emboscada para as tropas de João Pessoa ${ }^{20}$. Aqui, o sertanejo é astucioso e com essa capacidade de criar armadilhas se torna mais forte do que as tropas urbanas, que, pelo contrário, têm todas as forças bélicas possíveis e nenhuma inteligência. Os sertanejos são fracos, menos armados, mais sofridos pela seca e pelo sol, mas sua esperteza se sobrepõe à brutalidade dos soldados urbanos, no caso do artigo, ou à avareza e arrogância dos patrões e clérigos, no caso da peça. O mundo urbano e poderoso é fisgado pelas armadilhas do "povo miúdo".

40 João Pessoa e suas tropas urbanas são retratados como brutos e ignorantes. Tentam resolver tudo pela força, pela guerra, enquanto os sertanejos, calmos e astutos, pensam nos seus atos e resolvem as situações de maneira tranquila e engenhosa. Foi o que José Pereira fez ao descobrir as intenções de João Pessoa em bombardear Princesa. Em vez de desesperar-se, Pereira enviou um de seus homens para, calmamente, atravessar toda zona ocupada, descobrir o local onde estava a bomba e destruí-la com um tiro de rifle sem coronha.Tem-se aqui a oposição sertão versus cidade bem definida na caracterização dos personagens. Os sertanejos são astutos, calmos, defendem-se; os urbanos são brutos, ignorantes, invasores, afoitos a atacar, arrogantes e subestimam o adversário.

41 Essa caracterização serviria para o Auto da Compadecida. João Grilo, Chicó e os sertanejos típicos, como Luís do Triângulo, José Pereira e o cabra que desarmou a bomba, são espertos, planejam muito bem suas ações e atingem seus objetivos. Já o Padeiro e sua Mulher, que representam uma espécie de classe média urbana de Taperoá, são retratados como avarentos e desumanos. Subestimam a esperteza de João Grilo. Caem em suas armadilhas, como no caso do gato que "descome dinheiro". Esse modo de descrever o pobre como esperto e o rico e o urbano como bruto e ignorante funciona para praticamente todas as peças de Ariano Suassuna.

São, portanto, nesses pontos até aqui desenvolvidos - o ambiente, os personagens e a utilização de fontes populares -, que o teatro de Ariano e a seqüência de artigos que escreveu no Jornal da Semana, entre 1972 e 1974, podem ser lidos como formas distintas de criação de uma história familiar: variantes das narrativas genealógicas, tão comuns nas grandes famílias nordestinas. Nos dois tipos de produção, Ariano Suassuna valoriza determinados elementos em detrimento de outros na confecção de uma história de sua família, ou, poder-se-ia dizer, de sua tradução do Nordeste.Amadores e VioleirosO contexto em que, principalmente, o Auto da Compadecida foi escrito também é importante para se compreender esta relação entre genealogia e teatro. Em 1956, quando ela foi encenada pela primeira vez, Recife já contava com no mínimo uma grande companhia de teatro - TAP, Teatro de Amadores de Pernambuco- dirigida por Valdemar de Oliveira.Figura central neste processo de formação de um teatro recifense, Valdemar de Oliveira tinha trânsito livre pela elite pernambucana pós-revolução de 1930. Esta proximidade com algumas figuras chaves do Governo pernambucano colaboraram para que assumisse tanto a direção do Teatro Santa Isabel, em 1939, quanto à criação do TAP, em 1941. No interior desta companhia, Valdemar incentivou a vinda de diretores estrangeiros para formar atores e montar espetáculos no Recife. Seu 
intuito era compassar a capital pernambucana com o que havia de mais moderno no mundo do teatro, mas pouco incentivou autores locais.

O governador Agamenon Magalhães, aliado que acompanhava João Pessoa no momento em que ele foi assassinado por João Dantas, foi autor de um dos vários elogios empolgados de autoridades que se mostravam satisfeitas com o resultado de seus investimentos nas artes cênicas. Passaram pelo TAP importantes diretores e personalidades do mundo teatral como Turkow, Adacto Filho, em 1948, Ziembinski, em 1949, e, em seguida, Jorge Kossowski, Willy Keller, Flamínio Bolloni Cerri, Graça Melo e Bibi Ferreira.

O esforço de Oliveira em formar um elenco competente teve seu reconhecimento na montagem de Casa de Bernarda Alba de Frederico Garcia Lorca em 1955. Montada no Rio de Janeiro e em São Paulo, esta peça recebeu aplausos de Décio de Almeida Prado ${ }^{21}$.A maior parte das montagens do TAP, apesar de terem avançado na qualidade das encenações, era de textos traduzidos e que pouco dizia sobre o Nordeste. 0 ecletismo e o cosmopolitismo pretendido pelo TAP não agradavam muito Ariano Suassuna, Hermilo Borba Filho e seus outros colegas da Faculdade de Direito que se reuniram no grupo Teatro do Estudante de Pernambuco (TEP).

Apesar de o TEP ter uma curta duração (1946-1953), suas prerrogativas guiaram Ariano Suassuna na fatura de suas peças posteriores. O TEP buscava "levar o teatro ao povo", ou seja, buscavam incentivar autores locais que escrevessem histórias capazes de fazer sentido ao povo pobre de Pernambuco. Não se deveria perder de vista a realidade local no momento de escrita das peças.

Tendo Hermilo Borba Filho como uma espécie de mentor do grupo, já que, mais velho, tinha muita experiência em companhias teatrais, o TEP seguia muito fortemente as suas recomendações. Em um texto de 1947, Hermilo ressalta a importância de buscar repertório de temas e de técnicas dramáticas "genuinamente brasileiras", isto é, praticadas pelo "povo" para a construção de uma dramaturgia nacional.Ao mesmo tempo, demonstra a preocupação em educar o "povo" para o teatro, pois por mais que o "povo" conhecesse manifestações dramáticas - o bumba-meu-boi e o mamulengo seria necessário acostumá-lo a assistir peças nos moldes ocidentais. A busca por temas populares - as histórias de Lampião, Antônio Conselheiro e os heróis dos folhetos seria um pretexto para levar o teatro até o "povo" 22.

Estes foram os principais elementos que guiaram o TEP em sua atuação: a pesquisa de manifestações da cultura popular, o incentivo a autores que valorizassem temas ligados ao "povo", encenações gratuitas e fora do circuito oficial dos espetáculos. Essas prerrogativas criariam, segundo Borba Filho, tanto uma nova dramaturgia brasileira, como um público apto a apreciá-la.Nessa oposição entre TEP e TAP, Ariano Suassuna restabelece, em uma nova chave, a oposição entre sertão versus cidade; povo sertanejo versus elite urbana. O TAP - composto por profissionais liberais, produzindo montagens para seus pares; sendo financiado por aqueles que retiraram os Suassuna e seus aliados da cena política após 1930; com fortes pretensões cosmopolitas na escolha do seu repertório - não deixava de ser visto, por Ariano, como o braço dramatúrgico dos inimigos familiares. Em oposição, Ariano criará peças baseadas em folhetos populares, ambientadas no sertão e protagonistas sertanejos pobres.Junto com seus amigos do TEP, Ariano trouxe repentistas e violeiros para o Teatro Santa Isabel, sede da companhia de Valdemar de Oliveira. Ariano orgulha-se de apresentar a mesma audácia que teve seu pai $^{23}$. Se o seu pai era um amante da música sertaneja e trazia violeiros e 
cantadores para dentro de sua casa, de suas fazendas e do próprio Palácio do Governo, Ariano e seus parceiros do TEP, ao promoverem Festivais de Violeiros no Teatro Santa Isabel, fizeram reviver a mesma polaridade, entre gostos cosmopolitas das elites urbanas e ritmos populares tradicionais, para ficar nos termos de Lewin ${ }^{24}$.

Essa polaridade foi mais uma vez ativada na encenação de Auto da Compadecida, em 1956, no Teatro Santa Isabel. Suassuna conseguiu levar a temática sertaneja ao palco da elite urbana, que tanto seu pai como ele criticavam. O cenário, os personagens, as referências a cultura e tradições populares, as cantigas proclamadas por Grilo, as mentiras de Chicó, todos os elementos que caracterizavam o sertão, o sertanejo e, consequentemente, o universo defendido pelos Suassuna, estavam no centro do palco da casa de espetáculo financiada pelos seus opositores.

Se Ariano não foi capaz de escrever a biografia de seu pai nos anos de 1950, ele foi capaz de retratar o universo social que seu pai e toda sua parentela representavam em outro registro. Lançou-se como um dramaturgo original a partir da encenação de Auto da Compadecida - que teve reconhecimento imediato da crítica, basta ver os comentários de Décio de Almeida Prado a respeito das encenações feitas no Rio de Janeiro e em São Paulo - e de toda uma série de peças que traziam ao centro da cena uma forma muito singular de atribuir inteligibilidade ao mundo. A maneira como Ariano retrata o sertão, o sertanejo, a cidade e os homens urbanos o ancora em uma dada posição não apenas no interior de um campo literário ou dramatúrgico, mas sobretudo em um campo de disputa simbólica entre as elites nordestinas do que deve ser entendido por sertão, cidade e Nordeste.

A memória do pai, dessa forma, não foi cristalizada por uma narrativa biográfica, mas pela reconstrução de maneira ficcional do sertão, ambiente simbólico que toda a família lutava para construir como um marcador de origem e distinção. Ariano Suassuna, tal qual seus parentes que se dedicaram a escrita de genealogias e biografias, ao escrever suas obras ficcionais também colabora para selecionar elementos que caracterizam sua parentela, estabelecer os seus limites, definir os amigos e os inimigos.

\section{BIBLIOGRAFIA}

BORBA FILHO, Hemilo. Duas Conferências (Teatro: Arte do Povo; Reflexoes sobre a "Mise-em-Scène"). Diretoria de Documentação e Cultura/Prefeitura Municipal do Recife, Recife,1947.

CADENGUE, Antonio Edson. Tap: anos de aprendizagem; o teatro de amadores de Pernambuco (1941-1947). Dissertação de Mestrado. Faculdade de Comunicação e Artes, Universidade de São Paulo, São Paulo, 1989.

CADENGUE, Antonio Edson. Tap: sua cena e sua sombra - o teatro de amadores de Pernambuco (1948-1991). Tese de Doutorado. Faculdade de Comunicação e Artes, Universidade de São Paulo, São Paulo, 1991.

CAÑEDO, Letícia Bicalho. "Caminhos da Memória: Parentesco e Poder". In: Textos de História. v.2, n. 3. pp. 85-122, 1994. 
CAÑEDO, Letícia Bicalho. “As metáforas da família na transmissão do poder político: questões de método”. In: Cadernos Cedes, ano XVIII, no 42, pp.29-52, 1997.

COUTINHO, Natércia Suassuna Dutra Ribeiro. Paraíba - Nomes do Século: João Suassuna. A União Editora, João Pessoa, 2000.

DIMITROV, Eduardo. O Brasil dos espertos: Uma análise da construção social de Ariano Suassuna como "criador e criatura". Dissertação de Mestrado. Faculdade de Filosofia, Letras e Ciências Humanas, Universidade de São Paulo, São Paulo, 2006.

LEWIN, Linda. Política e Parentela na Paraíba. Um estudo de caso da oligarquia de base familiar. Record, Rio de Janeiro, 1993.

MAGALDI, Sábato. Panorama do teatro brasileiro. Difusão Européia do Livro, São Paulo, 1962.

MARQUES, Ana Claudia. Intrigas e Questões. Vingança de família e tramas sociais no sertão de Pernambuco. Relume-Dumará, Rio de Janeiro, 2002.

PRADO, Décio de Almeida. Teatro em Progresso: Critica teatral (1955-1964). Livraria Martins, São Paulo, 1964.

SUASSUNA, Ariano. O Desertor de Princesa. Recife: versão datilografada pelo autor, 1948.

SUASSUNA, Ariano. Uma Mulher Vestida de Sol. Imprensa Universitária, Recife 1964.

SUASSUNA, Ariano. A Pena e a Lei. Agir, Rio de Janeiro,1971.

SUASSUNA, Ariano. Estórias Mal Contadas. Suassuna e Politika. O Capitão Irineu Rangel. o Cabo e a Coragem. O Café do Mercado. O Revólver e a Faca. Esteja Preso. Questão de Princípio. Estória de Doido. Meu Tio e o Doido. 0 Doido de Patos. Patos, A Paraíba e o Mundo. Jornal da Semana, Recife, 7 A 13 Jan., 1973.

SUASSUNA, Ariano. Histórias de Meu Pai; Suassuna e o Barão de Itararé; Cantadores no Palácio do Governo; Castro Alves e os Cantadores; A Cantoria do Palácio; Suassuna e Carlos Dias Fernandes; C. D. Fernandes e os Cantadores; A Sextilha de José Clementino; O Repente de José Batista; A Resposta de José Clementino; Suassuna e os Doidos. Jornal da Semana, Recife, 21 A 27 Jan. 1973.

SUASSUNA, Ariano. Suassuna, Governador do Sertão; A Cidade e o Sertão; Reação dos Citadinos Contra o Campo; João Pessoa e Suassuna. Jornal da Semana, Recife, 9 A 15 Dez. 1973.

SUASSUNA, Ariano. Meu Prêmio e os Bodes. Charme Sertanejo ?; Quem Somos Nós; Porque Prefiro As Cabras; Cabras e Não Vacas. Jornal da Semana, Recife, 3 A 9 Jun. 1973.

SUASSUNA, Ariano. Maldade de Suassuna e Bondade de João Pessoa; Suassuna, Intrigante e Mentiroso; 0 Banquete de Princesa. Jornal da Semana, Recife, 13 A 19 Jan. 1974.

SUASSUNA, Ariano. Tavares e o Comandante João Costa; A Coluna Invencível; A Emboscada de Água Branca. Jornal da Semana, Recife, 3 A 9 Mar. 1974.

SUASSUNA, Ariano. Farsa da Boa Preguiça. José Olympio, Rio de Janeiro, 1974.

SUASSUNA, Ariano. O Santo e a Porca \& O Casamento Suspeitoso. José Olympio, Rio de Janeiro, 1979.

SUASSUNA, Ariano. Auto da Compadecida. Agir, Rio de Janeiro, 1999.

SUASSUNA, Ariano. “Homem Vestido de Sol”. Revista Palavra, Belo Horizonte, ano 1, n.10. 2000.

SUASSUNA, Ariano. Um Discurso Acadêmico. Folha de S. Paulo, 9/10/2000 E 8. SUASSUNA FILHO, João. Memórias... Histórias.... Ed. Do Autor, Recife. 2000.

SUASSUNA, Raimundo. Uma Estirpe Sertaneja: Genealogia da Familia Suassuna. João Pessoa: A União. 1993. 


\section{NOTAS}

1. PRADO, Décio de Almeida. Teatro em Progresso: Critica teatral (1955-1964), p.322. MAGALDI, Sábato. Panorama do teatro brasileiro.

2. MARQUES, Ana Claudia. Intrigas e Questões.

3. Diz Ariano sobre este projeto frustrado: "Na década de 1950 tentei escrever uma biografia de meu Pai, a Vida do Presidente Suassuna, Cavaleiro Sertanejo. Chamei assim porque sempre vi Suassuna como um Rei Cavaleiro: entre outras coisas ele tinha três Cavalos de sela, todos com nomes de Cangaceiros do grupo de Lampião: Passarinho, Bom-Deveras e Medalha. Não consegui escrever o livro, por causa da carga de sofrimento que ele me acarretava." In: SUASSUNA, Ariano. Um Discurso Acadêmico, p. E8. Folha de S.Paulo 9/10/2000.

4. CAÑEDO, Letícia Bicalho. Caminhos da Memória: Parentesco e Poder, p. 85-122; Idem. As metáforas da família na transmissão do poder político: questões de método, p. 29-52.

5. "Durante seu Governo, de 1924 a 1928, a preocupação fundamental de Suassuna foi com a zona rural, principalmente com o Sertão. Queria dotá-lo de estradas, de açudes, vê-lo coberto de gado, de pastagens e de algodão. A Capital da Paraíba, cidade de funcionários públicos, começou a reclamar. Injustamente, aliás. Primeiro porque, se essa era a preocupação principal do Governo, não era a exclusiva: bastaria o que Suassuna fez no Saneamento da Capital para defendê-lo da acusação de exclusivismo sertanejo. Depois, porque, quando Suassuna foi escolhido para governar a Paraíba, todo mundo sabia que ele era um homem do campo, um sertanejo: e como o Sertão nunca fora centro de atenção de nenhum Governo anterior, é claro que Suassuna iria sanar a injustiça." SUASSUNA, Ariano. Suassuna, Governador do Sertão; A Cidade e o Sertão; Reação dos Citadinos Contra o Campo; João Pessoa e Suassuna.

6. "Cito esses pormenores para que se veja que a luta política e armada que rebentou na Paraíba em 1930 já vinha se esboçando desde o Governo de Suassuna e era a conseqüência natural de um confronto entre a burguesia urbana de comerciantes e funcionários públicos, representada pela familia Pessoa, e os senhores rurais, representados por Suassuna, por José Pereira e por famílias, como a sertaneja dos Dantas, ou como a Cunha Lima, do Brejo." SUASSUNA, Ariano. Suassuna, Governador do Sertão; A Cidade e o Sertão; Reação dos Citadinos Contra o Campo; João Pessoa e Suassuna.

7. LEWIN, Linda. Política e Parentela na Paraíba. Um estudo de caso da oligarquia de base familiar, p. 313.

8. “Os Dantas, uma das famílias de minha mãe, tinham sido sempre inimigos do Doutor Epitácio Pessoa. Mas com o casamento de meu Pai e com a subida deste ao Governo, os Dantas consentiram em se aproximar de seus velhos adversários, os Pessoas, apoiados por Suassuna. De modo que, quando o Doutor João Pessoa ascendeu ao Governo, estavam do lado dele, João Suassuna, José Duarte Dantas, José Pereira, etc." SUASSUNA, Ariano. Maldade de Suassuna e Bondade de João Pessoa; Suassuna, Intrigante e Mentiroso; O Banquete de Princesa.

9. Há muitos incidentes importantes na sucessão de João Suassuna por João Pessoa que tornam o evento mais matizado e complexo. No entanto, este não é o foco deste artigo. Para mais detalhes, ver: LEWIN, Linda. op.cit.

10. Segundo Linda Lewin: "Antônio Suassuna, irmão do ex-governador, foi destituído por João Pessoa tanto da chefia política como da prefeitura de Brejo da Cruz, município que havia sido governado pelos Suassuna durante vinte anos. A atitude do governador valeu-lhe a admiração de boa parte dos setores urbanos de classe média. Antônio Suassuna dera proteção ao bandido Chico Pereira [Francisco Pereira Nóbrega], um dos participantes do célebre ataque a Souza realizado em 1924 por um grupo de cangaceiros liderados por Levino, irmão de Lampião. Antônio Suassuna chegara mesmo a alardear sua proteção ao fugitivo Chico Pereira (parente de seu irmão por casamento na familia Dantas) (...)".LEWIN, Linda. LEWIN, Linda. op.cit.

11. Ao mesmo tempo, é preciso relativizar o que é denominado de cangaceirismo, pois há uma tendência de sempre denominar o outro de "cangaceiro" e os próximos de "partidários". Essa tendência fica clara tanto nos artigos de Ariano Suassuna como nos jornais de 1930. Dependendo 
das alianças dos veículos da imprensa, os aliados tanto dos Pessoa como dos Suassuna eram chamados de "cangaceiros" ou de "partidários".

12. SUASSUNA, Ariano. Histórias de Meu Pai; Suassuna e o Barão de Itararé; Cantadores no Palácio do Governo; Castro Alves e os Cantadores; A Cantoria do Palácio; Suassuna e Carlos Dias Fernandes; C. D. Fernandes e os Cantadores; A Sextilha de José Clementino; O Repente de José Batista; A Resposta de José Clementino; Suassuna e os Doidos.

13. Diz a historiadora: “[...] crescimento econômico $e$ os interesses geoeconômicos divergentes ocasionaram rachaduras no conjunto dos valores, estilos e costumes, historicamente derivados de uma cultura rural, até então amplamente compartilhados pelas elites. A urbanização alterou modas, o discurso $e$ a identidade das elites durante a década de 1920, reforçando freqüentemente percepções dos interesses geoeconômicos diferenciadas entre litoral e o interior. A 'modernidade', numa capital de ares provinciais como Parahyba, significava ainda dançar as músicas européias - valsas e polcas-, embora o samba já houvesse começado a conquistar a elite social da nação, no Rio de Janeiro, como a dança brasileira moderna. Os políticos da capital paraibana viam em seus gostos cosmopolitas - mesmo que desatualizadosuma maneira de se distinguir de seus primos caipiras do interior que ainda preferiam cantar desafios como Suassuna - ou dançar os ritmos populares tradicionais de seus antepassados do século XIX". LEWIN, Linda. LEWIN, Linda. op.cit. p. 313-314.

14. SUASSUNA, Ariano. Auto da Compadecida, p. 21

15. A maioria das relações estabelecidas aqui entre o Auto da Compadecida e a construção genealógica de Suassuna seria perfeitamente possível de ser executada para as demais peças. Pelas limitações de espaço, neste artigo optou-se por tratar apenas do Auto da Compadecida e de A Pena e a Lei por serem as peças mais conhecida do público em geral, o que nos poupa paráfrases mais longas e detalhadas. Para uma análise das relações possíveis nas outras peças ver: DIMITROV, Eduardo. O Brasil dos espertos: Uma análise da construção social de Ariano Suassuna como "criador e criatura".

16. No conto popular original $O$ Castigo da Soberba essa história se aplicava a um coronel e sua esposa.

17. SUASSUNA, Ariano. Homem Vestido de Sol.

18. Nota-se que alguns personagens recebem nomes que Ariano cita em suas narrativas sobre os acontecimentos de 1930. Diz Suassuna em um de seus artigos do Jornal da Semana: "O Capitão Irineu Rangel é de Taperoá. É um homem bravo, de fala grave e descansada. Outra coisa: é um homem de bem, coisa que estou a cavalheiro para dizer porque ele pertence a uma familia que sempre foi adversária da minha família materna. Era porém amigo de meu Pai e passou por todas as lutas de Princesa, em 1930, lutando contra nós e contra José Pereira sem que qualquer ato de sua parte criasse a menor queixa em todos nós. E isso sem tergiversar nem um pouco no que ele julgava que era o cumprimento de seu dever". SUASSUNA, Ariano. Estórias Mal Contadas. Suassuna e Politika. O Capitão Irineu Rangel. o Cabo e a Coragem. O Café do Mercado. O Revólver e a Faca. Esteja Preso. Questão de Princípio. Estória de Doido. Meu Tio e o Doido. O Doido de Patos. Patos, A Paraíba e o Mundo. O Cabo Rangel também é citado em O Santo e a Porca (1957).

19. Dizia Ariano sobre a luta armada de Princesa em um de seus artigos: "Como já tem sido explicado várias vezes, a Polícia paraibana, depois de atacar Teixeira, em 28 de fevereiro de 1930, encaminhou-se em direção a Princesa, seguindo as tropas de Luís do Triângulo. Houve pequenos combates em Imaculada, Água Branca e Tavares. Aí, a Polícia foi encurralada, caindo numa armadilha que Luís do Triângulo lhe armou: entrou na cidade convencida de que a conquistara pondo em fuga o pessoal de Princesa; este, porém, tinha apenas ficado oculto nas imediações da cidade; e mal a polícia entrava lá, os guerrilheiros de José Pereira reapareceram e cercaram os soldados do Doutor João Pessoa. Toda a história da campanha de Princesa se desenrola em torno desse fato. O Doutor João Pessoa, ao saber do curso dos acontecimentos, declarou que tomaria Princesa em 48 horas. Passaram-se essas 48 horas e a polícia continuava cercada em Tavares. Terminou março: a polícia continuava lá. 0 Governo do Doutor João Pessoa contratou os serviços de um aviador que iria bombardear Princesa. Várias bombas começaram a ser 
fabricadas no Estado. A principal, era a de Campina Grande, destinada a ser jogada pelo avião sobre a cidade sertaneja rebelada. Sabedor disso, José Pereira despachou, de Princesa, um de seus guerrilheiros, que saiu de lá calmamente, atravessou toda a zona ocupada pela polícia, chegou em Campina Grande, informouse sobre o lugar onde estava sendo fabricada a bomba e então, dirigindo-se para lá, deu, nela, com um rifle sem coronha, um tiro que a fez explodir, levando pelos ares a bomba e a fábrica. 0 avião, por seu turno, caiu ao levantar vôo. Eram fatos tão desmoralizantes que era necessário apresentá-los como obra do acaso." SUASSUNA, Ariano. Tavares e o Comandante João Costa; A Coluna Invencível; A Emboscada de Água Branca.

20. Vale lembrar que Luís do Triângulo era da família de José Pereira e não um simples cabra, como a descrição de Ariano faz parecer.

21. PRADO, Décio de Almeida. op.cit., p. 322.

22. "Nós, os que nascemos no interior, nos acostumamos a ver, nas feiras dos domingos, os cegos cantando os feitos lendários desses homens que lutam, que amam, que sofrem, que morrem tragicamente, que constroem poemas com o sangue e com a vida e vemos como o povo rodeia esses cegos-cantadores, vemos o interesse despertado por esses feitos, vemos como o auditório chora, vibra e decora os versos ricos de humanidade, para repeti-los aos filhos que ainda vão nascer, às mulheres que ficaram em casa. Eram homens como eles os que viviam dentro desses versos, as aspirações e os problemas eram os mesmo, a luta era a mesma. Que se faça teatro com esse material e a multidão sairá das feiras para as casas de espetáculos e daí partirá a compreensão para as obras de elite. Que se acostume primeiro o povo com os dramas que vive dentro do seu sangue." BORBA FILHO, Hermilo. Duas Conferências, p. 9

23. "Lembro-me bem de que em 1946, quando realizei, no Santa Isabel, uma cantoria coletiva que foi o embrião dos futuros Festivais de violeiros (...) tive que lutar contra aqueles que se escandalizavam com o fato de eu querer levar 'Cantadores populares para o Santa Isabel'! Lembro-me bem de que o diretor do Teatro naquele ano, Valdemar de Oliveira, me dizia, desolado: 'Cantadores e violeiros no mesmo ambiente em que falaram ou recitaram versos Joaquim Nabuco, Castro Alves e Tobias Barreto'! (...) Lembro-me de ter objetado a Valdemar de Oliveira que Castro Alves e Tobias Barreto talvez até gostassem disso. O Diretor do Teatro, porém, não se deixou convencer. Forçado pelas circunstâncias, conforme ele mesmo me disse, iria concordar com o requerimento, feito pelo Diretório da Faculdade de Direito, do qual eu fazia parte em 1946. Mas, segundo disse, 'para ressalvar sua responsabilidade' iria fazer constar do despacho, como fez, que concordava somente tendo em vista 'o fim filantrópico' para o qual iria reverter a renda do espetáculo". SUASSUNA, Ariano. Histórias de Meu Pai; Suassuna e o Barão de Itararé; Cantadores no Palácio do Governo; Castro Alves e os Cantadores; A Cantoria do Palácio; Suassuna e Carlos Dias Fernandes; C. D. Fernandes e os Cantadores; A Sextilha de José Clementino; O Repente de José Batista; A Resposta de José Clementino; Suassuna es Doidos.

24. LEWIN, Linda. op.cit.

\section{RESUMOS}

Este artigo tem por objetivo explorar a maneira como o dramaturgo Ariano Suassuna constrói, por meio de sua produção teatral e de artigos publicados no periódico recifense Jornal da Semana, entre 1972 e 1974, certa memória familiar. O intuito é de apontar a forma como suas peças estão inseridas não só em um campo teatral emergente de Recife, mas também em uma disputa política e simbólica entre famílias da elite paraibana e pernambucana. $O$ assassinato de seu pai, tal como as represálias que seus parentes sofreram nos anos 30, inserem o dramaturgo em um campo de 
disputa pela identidade de sua família em relação aos seus adversários. A lógica privada da briga de família pode ser reconhecida nas opções artísticas assumidas pelo escritor, mesmo depois da aparente resolução da "intriga" que envolveu os Suassuna, Dantas e Pessoa pelo controle do Estado da Paraíba em 1930.

Cet article explore la façon dont le dramaturge Ariano Suassuna construit certains souvenirs de famille, à travers ses productions théâtrales et d'articles publiés dans l'hebdomadaire Jornal da Semana de Recife, entre 1972 et 1974. L'intention est de montrer que ses pièces ne sont pas seulement insérées dans un contexte théâtral émergent à Recife, mais aussi dans une dispute politique et symbolique entre les familles de l'élite des régions de Paraíba et de Pernambuco. L'assassinat de son père, et d'autres représailles que ses proches ont subi dans les années 1930, ont inscrit Ariano Suassuna dans un système d'affirmation de l'identité de sa famille en relation à celle de ses adversaires. Même après l'apparente résolution du conflit impliquant les familles Suassuna, Dantas et Pessoas pour le contrôle de l'Etat de Paraíba, la logique privée de la querelle de famille peut être reconnue dans les options artistiques assumée par l'écrivain.

\section{ÍNDICE}

Mots-clés: anthropologie, théâtre brésilien, Suassuna (Ariano), généalogie, mémoire et histoire Palavras-chave: antropologia, teatro brasileiro, Suassuna (Ariano), genealogia, memória e história

\section{AUTOR}

\section{EDUARDO DIMITROV}

Mestre e Doutorando em Antropologia Social pelo Departamento de Antropologia da Universidade de São Paulo e pesquisador FAPESP. 